TITLE:

\title{
An Original Patient-Derived Xenograft of Prostate Cancer With Cyst Formation.(Abstract_要旨)
}

$\operatorname{AUTHOR}(\mathrm{S})$ :

Yoshikawa, Takeshi

\section{CITATION:}

Yoshikawa, Takeshi. An Original Patient-Derived Xenograft of Prostate Cancer With Cyst Formation.. 京都大学, 2017, 博士(医学)

ISSUE DATE:

2017-05-23

URL:

https://doi.org/10.14989/doctor.k20558

RIGHT: 


\begin{tabular}{|l|l|c|c|}
\hline 京都大学 & 博士 (医 学) & 氏 名 & 吉川 武志 \\
\hline & An Original Patient-Derived Xenograft of Prostate Cancer With \\
論文題目 & Cyst Formation \\
& （囊胞形成を特徵とした新規前立腺癌異種移植モデル）
\end{tabular}

\section{(論文内容の要旨)}

【背景】新規抗腫瘍薬の開発にあたり、前臨床段階の実験系がヒト生体内におけ る癌の複雑な病態を反映していないことが、後の臨床試験における成功率の低さの一因で あると考えられている。近年、前立腺癌における去勢抵抗性獲得メカニズムの理解が進ん だことにより、いくつかのアンドロゲン受容体経路を標的とする新規薬剤が開発された が、その効果は限定的である。したがって、前立腺癌の生物学的多様性を再現することが 可能な前臨床段階の実験系の確立が必要とされている。本研究では、治療効果予測に有用 なバイオマーカー探索や、前立腺癌の病態メカニズムの理解に有用な新規患者由来異種移 植片（PDX）モデルを確立した。

【方法】日本人前立腺癌患者から採取した前立腺癌腫瘍組織片を重症複合免疫不全 (SCID) マウス (雄) の皮下に移植したところ、安定して継代可能な PDX マウスモデル の樹立に成功し、KUCaP3 と命名した。移植マウスの去勢前後の腫瘍体積の変化を経時的 に観察した。KUCaP3 のアンドロゲン受容体（AR）、前立腺特異抗原（PSA）、および他 の分子マーカーの発現を免疫組織学的に検討した。 $A R$ 遺伝子の変異の有無を塩基配列分 析によって調べた。液体クロマトグラフィー質量分析法 (LC/MS/MS) を用いて、KUCaP3 腫瘍の囊胞内容液およびマウス血清のプロテオミクス分析を行った。

【結果】新規 PDX である KUCaP3 は、60\%の腫瘍形成率で継代可能であった。 KUCaP3 腫瘍は囊胞を形成し、宿主マウスの去勢によって一旦縮小寸るものの、 数ヶ月後に約 $50 \%$ の確率で去勢抵抗性を獲得した。免疫組織化学的染色では AR、PSA、CK18、AMACR 陽性、CK5 / 6 および ERG 陰性を示した。KUCaP3 腫瘍における $A R$ 遺伝子は、リガンド結合ドメインにおけるコドン 875 のアミ ノ酸置換（H875Y）をもたらすヌクレオチドの点変異（㺼AT $\rightarrow$ CAT）を有して いた。KUCaP3 腫瘍の囊胞液および担癌マウスの血清中のPSA は高值を示した。 $\mathrm{LC} / \mathrm{MS} / \mathrm{MS}$ 分析では KUCaP3 腫瘍の囊胞液中から 23 種のヒト由来タンパク質を 検出した。

【結論】襄胞形成を伴うアンドロゲン依存性前立腺癌新規 PDX モデル KUCaP3 を樹立した。PSA を含むいくつかのタンパク質が、囊胞液および担癌マウスの 血清中から検出された。モデル動物の少ない前立腺癌研究の中で、本 PDX モデ ルは前立腺癌の臨床像をよく再現し、前立腺癌診療に応用可能なバイオマーカ 一探索や治療シーズ解析に有用なモデルと考えられる。
（論文審査の結果の要旨）

前立腺癌研究においては腫瘍の heterogeniety が問題となり、それを克服する ためのアプローチとして患者由来異種移植片（PDX）モデルが有用である。申請者ら は、治療効果予測に有用なバイオマーカー探索や前立腺癌の病態メカニズムの理解に有用 な新規PDX モデルを確立し、その臨床的応用を検討した。

日本人前立腺癌患者功採取した前立腺癌腫瘍組織片を重症複合免疫不全 (SCID) マウ ス (雄) の皮下に移植したところ、安定して継代可能な PDX マウスモデルの樹立に成功 し、KUCaP3 と命名した。新規 PDX である KUCaP3 は、60\%の腫瘍形成率で継代 可能であった。 KUCaP3 腫瘍は囊胞を形成し、宿主マウスの去勢によって一旦 縮小寸るものの、数ヶ月後に約 $50 \%$ の確率で去勢抵抗性を獲得した。免疫組織 化学的染色では AR、PSA、CK18、AMACR 陽性、CK5 / 6 および ERG 陰性を示 した。KUCaP3 腫瘍における $A R$ 遺伝子は、リガンド結合ドメインにおけるコド ン 875 のアミノ酸置換 $(\mathrm{H} 875 \mathrm{Y})$ をもたらすヌクレオチドの点変異 $(\underline{\mathbf{T} A T} \rightarrow \underline{\mathbf{C A T}})$ を有していた。KUCaP3 腫瘍の囊胞液および担癌マウスの血清中の PSA は高值 を示した。LC/MS/MS 分析では KUCaP3 腫瘍の囊胞液中から 23 種のヒト由来タ ンパク質を検出した。

以上の結果は、本 PDX モデルが前立腺癌の臨床像をよく再現し、前立腺癌診 療に忘用可能なバイオマーカー探索や治療シーズ解析に有用なモデルと考えら れるという点で、前立腺癌研究に寄与寸るところが多い。

したがって、本論文は博士（医学 ）の学位論文として価值あるものと認める。

なお、本学位授与申請者は、平成 29 年 3 月 7 日実施の論文内容とそれに関連した試 問を受け、合格と認められたものである。 